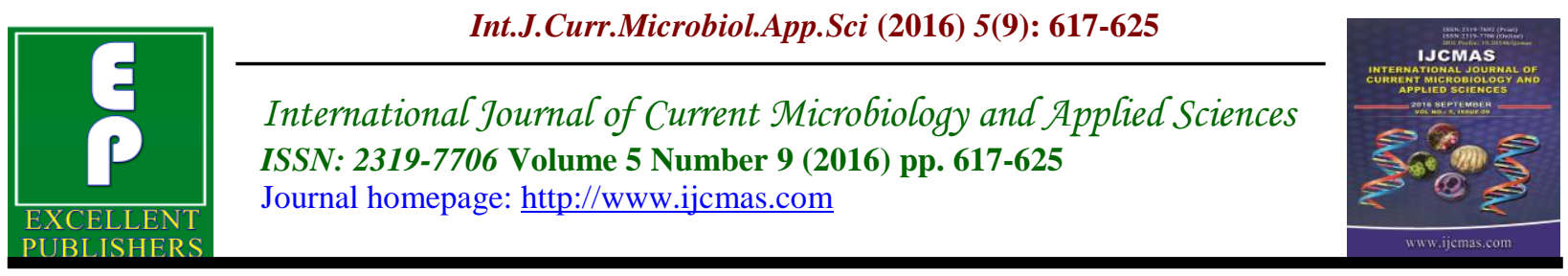

Original Research Article

http://dx.doi.org/10.20546/ijcmas.2016.509.070

\title{
Identification of Bacteria that Contaminate Stored Streptomycin Species at $4^{\circ} \mathrm{C}$
}

\author{
Aurpita Shaha $^{1,2 *}$, Ariful Haque ${ }^{3}$, Uzzal Haque ${ }^{4}$ and Anwar UI Islam² \\ ${ }^{1}$ Department of Molecular Pharmacology, Institute of Biomedical sciences, \\ Tokushima University Graduate School, Tokushima, Japan \\ ${ }^{2}$ Department of Pharmacy, Rajshahi University, Rajshahi-6205, Bangladesh \\ ${ }^{3}$ Institute of Biological Science, Rajshahi University, Rajshahi, Bangladesh \\ ${ }^{4}$ Department of Pharmacy, Jessore University of Science and Technology \\ *Corresponding author
}

\section{Keywords}

Bacterial culture, contamination, antibiotic, phylogenetic tree, Streptomycessp., Bacillus sp.

\section{Article Info}

Accepted:

20 August 2016

Available Online:

10 September 2016

\section{A B S T R A C T}

The present study aims at exploring the bacteria that contaminate potential antibiotics producing indigenous marine Streptomyces species that stored at $4{ }^{\circ} \mathrm{C} 4$. Three organisms isolated from stored Streptomyces strain designated as AIAS-5, AIAS-10 and AIAS-39was subjected for taxonomic characterization and identification as they have moderate to high antibacterial activity. It was found that the strain was closely resembled to Bacillus sp. This identification was further confirmed by the $16 \mathrm{~S}$ rDNA sequence analysis. The result of BLAST search and phylogenetic analysis showed that the strain AIAS-5 was a type strain of Bacillus pumilus SAFR-032 with $98 \%$ similarity as it formed a distinct branch with other strains of this species; AIAS-10 shows 99\% similarity with Bacillus amyloliquefaciens, phylogenetic tree build from the forward sequence of this strain from a distinct with separate branch in the tree and Strain AIAS-39 was identified as Bacillus toyonensis with $97 \%$ similarity. Strains AIAS-39 may be identified as a new species of Bacillus species as according to $1 \%$ difference in sequence similarity is needed to warrant a new species name. To confirm it is a new species further work on its phenotypic characteristics is going on.

\section{Introduction}

The discovery of antibiotic phenomenon was developed due to the contamination of an unknown organism to the culture medium. Fleming's accidental discovery and isolation of penicillin in September 1928 marks the start of modern antibiotics. The first antibiotics were of natural origin, e.g. penicillin produced by fungi in the genus Penicillium, or Streptomycin from bacteria of the genus Streptomyces. Besides actinomycete bacteria, another important source of antibiotics is the genus Bacillus (Logan and De Vos, 2009). The genus Bacillus has been known as an important source of antibiotic producers since the "golden age" of antibiotic discovery (Schaffer, 1969). Just in the organism $B$. subtilis, 12 antibiotic compounds have been 
isolated from different strains (Stein, 2005). Many of the antibiotics from Bacillus are peptide compounds that are synthesized either ribosomally or non-ribosomally (by non-ribosomal peptide syntheses) and are resistant to the action of proteases (Schaffer, 1969; Nakano and Zuber, 1990; Stein, 2005). Two peptide antibiotics produced by Bacillus have seen widespread use: bacitracin and polymyxin-B. Bacitracin is a cyclic dodecapeptide produced by both $B$. subtilis and B. licheniformis, and is active mainly against Gram-positive organisms by inhibiting cell wall synthesis (Tay, 2010). Bacitracin is one of the active ingredients in the topical agents Neosporin and Polysporin, and is also used in livestock feed (Tay, 2010). Although this antibiotic has seen 50 years of use, resistance to bacitracin is still rare (Tay, 2010). Polyketide antibiotics are also produced by Bacillus such as difficidin, which has broad-spectrum activity against Gram-positives and Gram-negatives. Bacillus continues to be a good source of new antibiotics today, such as the recent discovery of a novel lantibiotic from $B$. licheniformis (Dischinger, 2009). Multi drug resistant bacteria is becoming a worldwide problem posing health risks for all spectrum of patients and here are several mechanisms by which bacteria are resisting antibiotics (Sathish Kumar and Bhaskara Rao, 2012), and due to the problems, the search for new antibiotics is highly needed.

In this study way we have preserved isolated antimicrobial producing organisms in our Laboratory since 2010 , for further studies at $4^{\mathrm{O}} \mathrm{C}$. We have observed, sometimes this preserved Streptomyces species become contaminated by some unknown organisms. Since we have studied in our previous experiment, antibiotic producing organisms don't allow the growth of other testing organisms. Our study aims at exploring the bacteria that contaminate the potential antibiotics producing indigenous marine
Streptomyces isolated from the Sundarbans beach in the Northern Parts of Bangladesh.

\section{Materials and Methods}

Isolation of Microorganisms responsible for contamination of Streptomyces from Soil Samples

For isolation of antibiotic producing Streptomyces from soil samples protocol developed by Dr. Jerry Ensign was adopted (Bernard, 2007). The Isolated species of ANAM-5, AIAH-10 and ANAM-39 were collected from marine soil and stored for further studies in the Microbiology laboratory of Pharmacy, University of Rajshahi from $2009-2013$ at $4^{\circ} \mathrm{C}$. The isolated Streptomyces Species frequently contaminated by others bacteria during storage. Three new strains were isolated and designated as AIAS-5, AIAS-10 and AIAS39 which are respectively found in ANAM5, AIAH-10 and ANAM-39. Our aim of the study was characterization and molecular identification of those contaminating Bacteria.

\section{Morphological studies of the isolated strains}

To identify the selected strains, the following morphological characters were studied. i) Non-microscopic studies like agar colony; agar slant and nutrient broth culture test were observed and noted (Table-2).

\section{Microscopic observation}

The sizes and shapes of the (vegetative cell) bacteria were determined. The arrangements of the cells whether present singly, in rod shaped, in pairs or chains were also observed. Motility of the organism was observed and gram-staining test was done to characterize the organism (Fig-1,2,3 and Table-1). 
Gram staining tests were done according to the standard method (Table-3). The presence of crystal Violet color indicated the gram positive and safarine color indicated the gram-negative organisms (Koby et al., 2004).

\section{Biochemical testes used to characterize the isolated strains}

\section{Fermentation test}

This test is used to differentiate the organisms that ferment carbohydrate (such as glucose, galactose and sucrose). Oxidation fermentation medium is used in the fermentation test of carbohydrate (Table2).

\section{Citrate utilization test}

This test was based on the ability of an organism to use citrate as its only carbon source and ammonia as its only source of nitrogen. The test organism was cultured in a medium, which contains sodium acetate, an ammonium salt and the indicator bromothymol blue, Koser's citrate medium was used in citrate utilization test (Table-2).

\section{Indole test}

This test demonstrates the ability of certain bacteria to decompose the amino acid tryptophan to indole, which accumulates in the medium (Table-2). Indole is then tested by a calorimetric reaction with $\mathrm{p}$-dimethylaminobenzaldehyde. The $\mathrm{pH}$ of the media was adjusted to 7.4 and sterilized by autoclaving at $121^{\circ} \mathrm{C}$ for 15 minutes and stored at $4{ }^{0} \mathrm{C}$.

\section{Phylogenetic Classification and Identification of the Isolated Strains:}

\section{Molecular identification of bacteria}

The identity of the isolate was determined by sequence analysis of the $16 \mathrm{~S}$ rDNA gene.
The overnight cultured bacterial cells were lysed with lysozyme and the DNA was extracted by the phenol: chloroform (1:1) extraction method described by Ausubel (1987). The 16S rDNA was amplified in PCR with the primer pair BcF (TAC GGYTACCTTGTTACGACTT) and BtF (AGAGTTTGATCMTGGCTCAG). The amplified region was then sequenced and subject to BLAST analysis for analyzing its phylogeny (Strubeet, 1937)

\section{PCR}

The Polymerase Chain Reaction (PCR) is a powerful and sensitive technique for DNA amplification (Saiki,1985). Taq DNA Polymerase is an enzyme widely used in PCR (Powellet, 1987).

The following guidelines are provided to ensure successful PCR using NEB's Taq DNA Polymerase. These guidelines cover routine PCR. Amplification of templates with high GC content, high secondary structure, low template concentrations, or amplicons greater than $5 \mathrm{~kb}$ may require further optimization.

\section{Agarose gel electrophoresis}

Gel electrophoresis is a widely used technique for the analysis of nucleic acids and proteins. Most every molecular biology research laboratory routinely uses agarose gel electrophoresis for the preparation and analysis of DNA. Agarose gel electrophoresis was used to determine the presence and size of PCR products.

\section{Cutting out the DNA band}

DNA band was visualized in an ethidium bromide stained gel, in a dark-room on a UV light-box (a trans-illuminator). Lab coat and gloves were worn for protection of eyes and body from dangerous UV. Looking at UV 
with unprotected eyes was avoided. This is because the UV mutagenesis the DNA at a measurable rate. A scalpel blade was used to cut around the band of interest.

Then the trans-illuminator was Switch off, and the white light was switch on and carefully the band from the gel was remove and it was placed on the glass. Place the excised band was placed in a $1.5 \mathrm{~mL}$ microcentrifuge tube.

\section{Precipitation of rDNA with sodium acetate and ethanol}

For ethanol precipitation of DNA from solution, the solution needs to have a high salt concentration. Usually, this must be added in the form of sodium acetate (Na-Ac, the best salt for this purpose) or $\mathrm{NaCl}$. After the solution has been adjusted with salt, $100 \%$ ethanol is added so the final ethanol concentration is $70 \%$ and the final salt concentration is $0.3 \mathrm{M}$.

\section{S rDNA gene sequencing and blast}

16S rDNA gene sequences contain hypervariable regions that can provide species-specific signature sequences useful for bacterial identification. The amplified region was then sequenced and subject to BLAST analysis for analyzing its phylogeny.

\section{Result and Discussion}

\section{Isolation and Characterization of Bacteria}

Isolated pure culture of bacteria responsible for contamination were studied for morphological and biochemical characteristics. With an attempt to identify the selected strains, the following morphological characters were studied.

\section{Morphological observation}

\section{Visual Observation}

The bacterial species isolated from the contaminated stored Streptomyces species grew on 1st day and it becomes white colonies on 2 days. As the time passes the mycelium remains sticky and spread over the Petridis and turn into light brown in color.

\section{Bacterial Strain isolated from contaminated Streptomyces Strain}

\section{Microscopic observation}

The first step in the identification of an unknown bacterial organism is to learn as much as possible about its morphological characteristics. The results are presented in (Table-1).

Table.1 Microscopic observation of isolated strains

\begin{tabular}{|c|c|c|c|c|l|}
\hline Strain & $\begin{array}{c}\text { Gram } \\
\text { staining }\end{array}$ & $\begin{array}{c}\text { Cell } \\
\text { shape }\end{array}$ & Arrangement & $\begin{array}{c}\text { Motility } \\
\text { test }\end{array}$ & \multicolumn{1}{|c|}{ Comment } \\
\hline AIAS-5 & + & Bacillus & Single & + & May be Bacillus \\
\hline AIAS-10 & + & Bacillus & Single & + & May be Bacillus \\
\hline AIAS-39 & + & Bacillus & Single & + & May be Bacillus \\
\hline
\end{tabular}


Table.2 Visual observation on agar slant and broth medium

\begin{tabular}{|l|c|c|c|c|}
\hline Strain & $\begin{array}{c}\text { Colony } \\
\text { color }\end{array}$ & $\begin{array}{c}\text { Colony } \\
\text { type }\end{array}$ & $\begin{array}{c}\text { Colony } \\
\text { form }\end{array}$ & $\begin{array}{c}\text { Growth in nutrient } \\
\text { broth medium }\end{array}$ \\
\hline AIAS-5 & White & Wet & Circular & Surface \\
\hline AIAS-10 & White & Wet & Circular & Surface \\
\hline AIAS-39 & White & Wet & Circular & Surface \\
\hline
\end{tabular}

Table.3 Biochemical tests Used to characterize the isolated strains-

\begin{tabular}{|c|c|c|c|c|}
\hline Strain & $\begin{array}{l}\text { Gram- } \\
\text { staining }\end{array}$ & $\begin{array}{l}\text { Fermentation } \\
\text { test }\end{array}$ & $\begin{array}{l}\text { Citrate } \\
\text { Utilization } \\
\text { test }\end{array}$ & $\begin{array}{l}\text { Indole } \\
\text { Test }\end{array}$ \\
\hline AIAS-5 & + & + & + & + \\
\hline $\begin{array}{l}\text { AIAS- } \\
10\end{array}$ & + & + & + & + \\
\hline $\begin{array}{l}\text { AIAS- } \\
39\end{array}$ & + & + & + & + \\
\hline
\end{tabular}

Fig.1,2 \& 3 Visual Observation of AIAS-39; Visual observation of AIAS-5;

Visual Observation AIAS-10
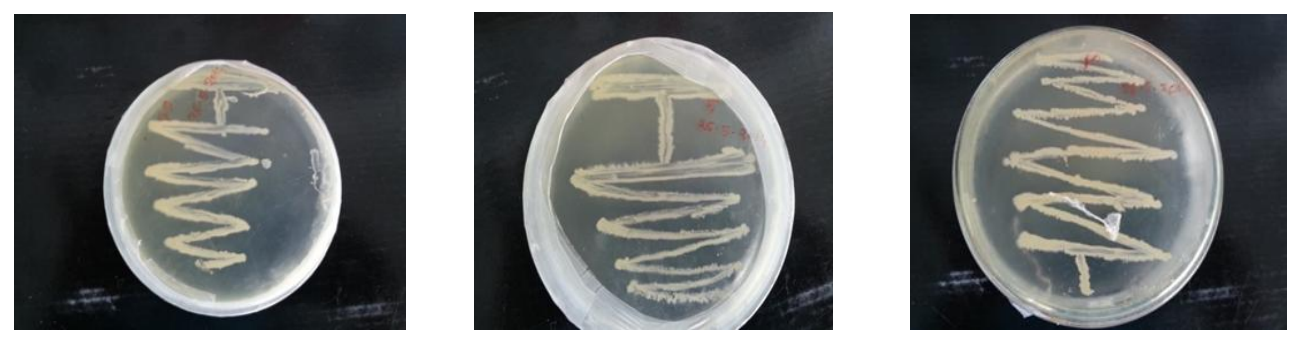

Fig.4 Microscopic View of Isolated AIAS-5, (A) magnification X 200, (B)magnification X 400

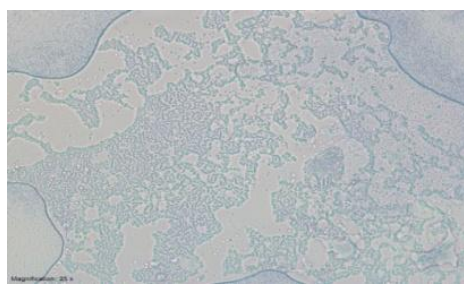

( A )

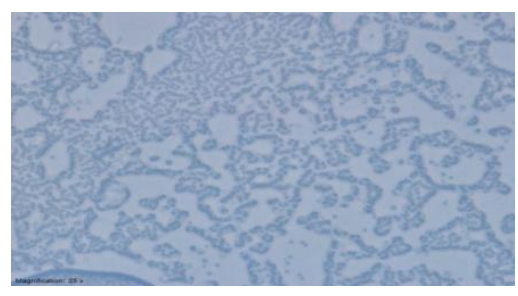

( B ) 
Fig.5 Microscopic View of Isolated AIAS-10, (A) magnification X 200 (B) magnification X 400

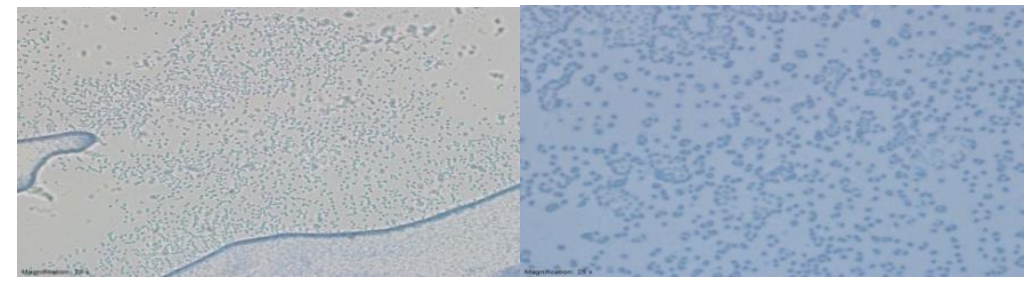

( A )

( B )

Fig.6 Microscopic View of Isolated AIAS-39, (A) magnification X 200 (B) magnification X 400

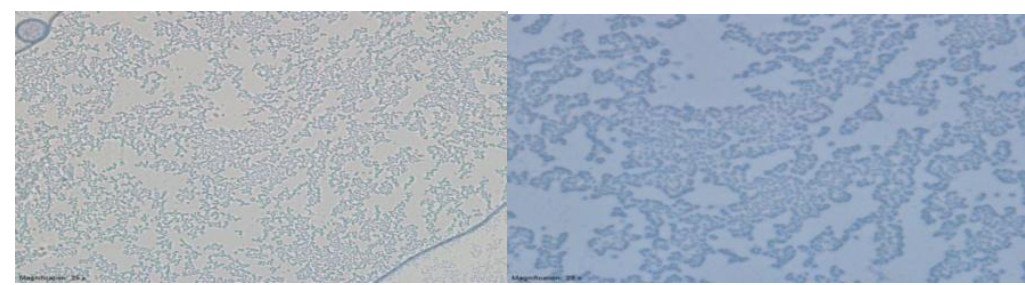

(A)

(B)

Fig.7 Phylogenetic tree and sequencing alignment showing the relationship between strains AIAS-5 and representative species of the genus Bacillus based on partial 16S rDNA gene sequences. (This tree was made from forward sequence).

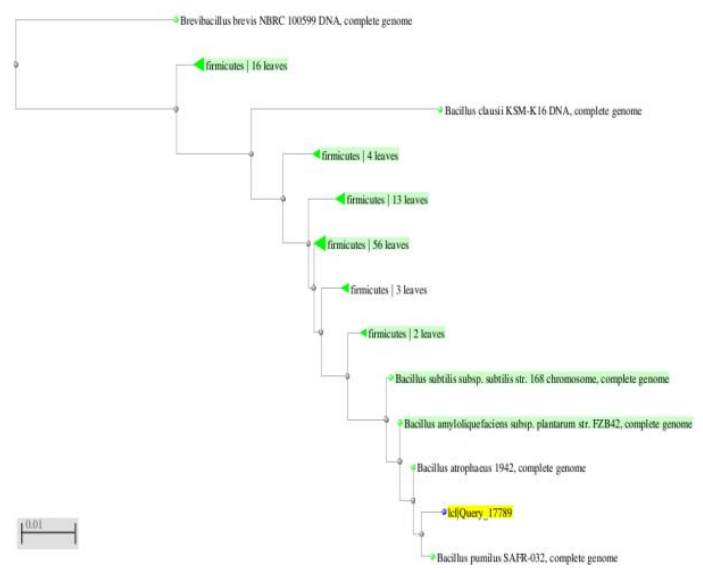

\begin{tabular}{|l|l|l|l|l|l|l|}
\hline Description & $\begin{array}{l}\text { Max } \\
\text { score }\end{array}$ & $\begin{array}{l}\text { Total } \\
\text { score }\end{array}$ & $\begin{array}{l}\text { Query } \\
\text { cover }\end{array}$ & $\begin{array}{l}\text { E } \\
\text { value }\end{array}$ & Ident & Accession \\
\hline $\begin{array}{l}\text { Bacillus pumilus } \\
\text { SAFR-032 }\end{array}$ & 1581 & 12916 & $98 \%$ & 0.0 & $98 \%$ & NC_009848 \\
\hline $\begin{array}{l}\text { Bacillus } \\
\text { amyloliquefaciens, } \\
\text { subsp. plantarum str. } \\
\text { FZB42 }\end{array}$ & 1458 & 15197 & $97 \%$ & 0.0 & $96 \%$ & NC_009725.1 \\
\hline $\begin{array}{l}\text { Bacillus atrophaeus } \\
\mathbf{1 9 4 2}\end{array}$ & 1452 & 11762 & $98 \%$ & 0.0 & $96 \%$ & NC_014639.1 \\
\hline
\end{tabular}


Fig.8 Phylogenetic tree and sequencing alignment showing the relationship between strains AIAS-39 and representative species of the genus Bacillus based on partial 16S rDNA gene sequences. (This tree was made from forward sequence).

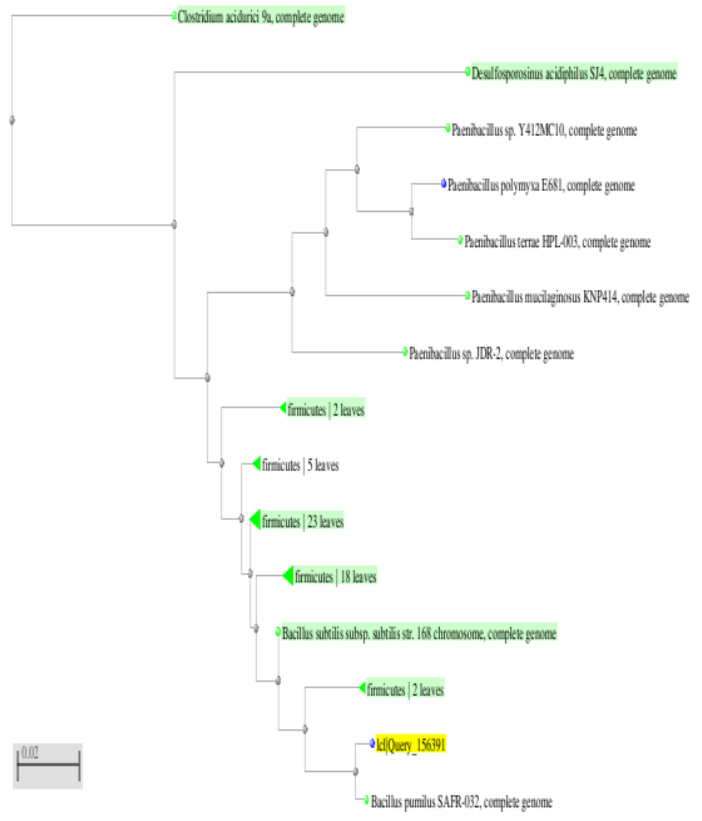

\begin{tabular}{|l|c|c|c|c|l|l|}
\hline Description & $\begin{array}{l}\text { Max } \\
\text { score }\end{array}$ & $\begin{array}{l}\text { Total } \\
\text { score }\end{array}$ & $\begin{array}{l}\text { Query } \\
\text { cover }\end{array}$ & $\begin{array}{l}\text { E } \\
\text { value }\end{array}$ & Ident & Accession \\
\hline $\begin{array}{l}\text { Bacillus } \\
\text { amyloliquefaciens } \\
\text { subsp. plantarum } \\
\text { str. FZB42, } \\
\text { complete genome }\end{array}$ & 878 & 13128 & $99 \%$ & 0.0 & $95 \%$ & NC_009725.1 \\
\hline $\begin{array}{l}\text { Bacillus subtilis } \\
\text { subsp. subtilis str. } \\
\text { 168 chromosome, } \\
\text { complete genome }\end{array}$ & 872 & 14195 & $99 \%$ & 0.0 & $95 \%$ & NC_000964.3 \\
\hline $\begin{array}{l}\text { Bacillus } \\
\text { atrophaeus 1942, } \\
\text { complete genome }\end{array}$ & 867 & 10081 & $99 \%$ & 0.0 & $95 \%$ & NC_014639.1 \\
\hline
\end{tabular}

Fig.9 Phylogenetic tree and sequence alignments' showing the relationship between strains AIAS-10 and representative species of the genus Bacillus based on partial 16S rDNA gene sequences. (This tree was made from forward sequence)

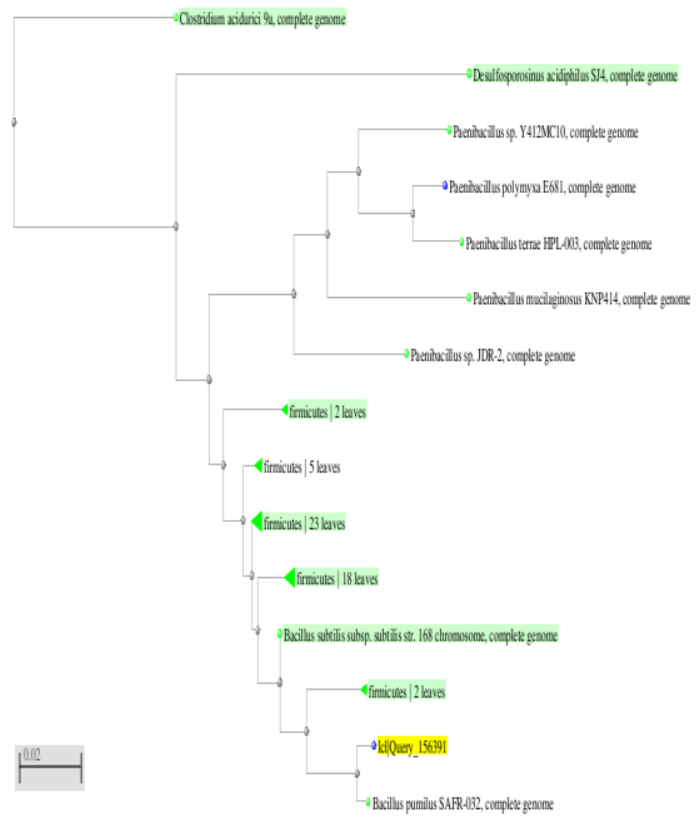

\begin{tabular}{|l|c|c|c|c|l|l|}
\hline Description & $\begin{array}{l}\text { Max } \\
\text { score }\end{array}$ & $\begin{array}{l}\text { Total } \\
\text { score }\end{array}$ & $\begin{array}{l}\text { Query } \\
\text { cover }\end{array}$ & $\begin{array}{l}\text { E } \\
\text { value }\end{array}$ & Ident & Accession \\
\hline $\begin{array}{l}\text { Bacillus } \\
\text { amyloliquefaciens } \\
\text { subsp. plantarum } \\
\text { str. FZB42, } \\
\text { complete genome }\end{array}$ & 878 & 13128 & $99 \%$ & 0.0 & $95 \%$ & NC_009725.1 \\
\hline $\begin{array}{l}\text { Bacillus subtilis } \\
\text { subsp. subtilis str. } \\
\text { 168 chromosome, } \\
\text { complete genome }\end{array}$ & 872 & 14195 & $99 \%$ & 0.0 & $95 \%$ & NC_000964.3 \\
\hline $\begin{array}{l}\text { Bacillus } \\
\text { atrophaeus 1942, } \\
\text { complete genome }\end{array}$ & 867 & 10081 & $99 \%$ & 0.0 & $95 \%$ & NC_014639.1 \\
\hline
\end{tabular}


The substrate mycelia were well developed. The aerial mycelia formed rod shaped spore chains.

The culture characteristics results- (Table-2) and Biochemical tests Used to characterize the isolated strains shown in Table-3.

It was found that the strain were closely resembled to Bacillus Spp. This identification was further confirmed by the $16 \mathrm{~S}$ rDNA sequence analysis.

The result of BLAST search and phylogenetic analysis (Figure 7) showed that the strain AIAS-5 is a type strain of Bacillus pumilus SAFR-032 with 98\% similarity as it formed a distinct branch with other strains of this species.

In case AIAS-10, BLAST search, DNA homology experiment and phylogenetic analysis of both reverse and forward sequence of $16 \mathrm{~S}$ rRNA gene, forward sequence shows 99\% similaritywith Bacillus amyloliquefaciens. The phylogenetic tree build from the forward sequence of this strain form a distinct and separate branch in the tree (Figure not shown). On the other hand, in case of AIAS-39, based on the result of BLAST search and phylogenetic analysis (Figure 8) using the forward sequence of 16S rRNA gene, the sequences show 97\% similarity with identified as Bacillus toyonensis. The strain AIAS-39 may be identified as a new species of Bacillus species as according to $1 \%$ difference in sequence similarity is needed to warrant a new species name (Clarridge, 2004).

To confirm it as a new species further work on its phenotypic characteristics is going on. All these three species are Bacillus Species. Bacillus species are rod-shaped, endosporeforming aerobic or facultative anaerobic,
Gram-positive bacteria; in some species cultures may turn Gram-negative with age.

\section{Analysis of the forward sequence of AIAS-5}

The forward sequence (780 nt long) was matched with other sequences deposited in the database EMBL/DDBJ/GeneBank using BLAST. The result of BLAST search is shown in figure-7.

\section{Analysis of the forward sequence of AIAS-39}

The forward sequence (723 nt long) was matched with other sequences deposited in the database EMBL/DDBJ/GeneBank using BLAST. The result of BLAST search is shown in below- Fig-8

In conclusion, the desired outcome of this research work was to explore the bacteria that were responsible for the contamination of potential antibiotic producing Streptomyces Species. Three organisms were isolated from the stored Streptomyces strain in our Microbiology laboratory, University of Rajshahi. These strains designated as AIAS-5, AIAS-10 and AIAS-39 were subjected for taxonomic characterization and identification as they have moderate to high antibacterial activity. It was found that the strain was closely resembled to Bacillus $S p$. This identification was further confirmed by the 16S rDNA sequence analysis. The result of BLAST search and phylogenetic analysis showed that the strain AIAS-5 was a type strain of Bacillus pumilus SAFR-032 with 98\% similarity, Strain AIAS-39 was identified as Bacillus toyonensis with 97\% similarity and AIAS-10 shows 99\% similarity with Bacillus amyloliquefaciens.

\section{Acknowledgement}

I am grateful to Md. Ajijur Rahman, Assistant professor, Department of 
Pharmacy, Rajshahi University, for analyzing the 16s rDNA sequencing of the isolates.

\section{References}

Ahmed, S.M., Jakribettu, R.P., Koyakutty, S. 2012. Urinary Tract Infections - An overview on the Prevalence and the Anti-biogram of Gram Negative.

Dischinger, J., Josten, M., Szekat, C., Sahl, H. Bieberbaum, G. 2009. Production of the novel two peptide lantibioticlichenicidin by Babilluslicheniformis DSM 13 . Public Library of Sci. One, 4: 1-11.

Logan, N., De Vos, P. 2009. Bergey"s Manual of Systematic Bacteriology. New York, NY: Springer Sci., Genus I. Bacillus. 3: 21-128.

Nakano, M., Zuber, P. 1990. Molecular biology of antibiotic production in Bacillus.Critical Rev. Biotechnol., 10: $223-240$.

Schaffer, P. 1969. Sporulation and the production of antibiotics, exoenzymes, and exotoxins. Bacteriol. Rev., 33: 4871.

Sathish Kumar, S.R., Bhaskara Rao, K.V. 2012. In-vitro antimicrobial activity of marine actinobacteria against multidrug resistance Staphylococcus aureus. Asian Pacific Trop. Biomed., S1802-S1807.

Stein, T. 2005. Bacillus subtilis antibiotics: structures, syntheses, and specific functions. Mol. Microbiol., 56: 845 857.

Saiki, R.K., Scharf, S., Faloona, F., Mullis, K.B., Horn, G.T., Erlich, H.A., Arnheim, N. 1985. Enzymatic amplification of beta-globin genomic sequences and restriction site analysis for diagnosis of sickle cell anemia. Sci., 230(4732): 1350-1354.

Powell, $\quad$ L.M., Wallis, $\quad$ S.C., Pease, R.J., Edwards, Y.H., Knott, T.J., Scott, J. 1987. A novel form of tissue-specific RNA processing produces apolipoprotein-B48 in intestine. Cell, 50(6): 831-40.

Ausubel, F.M., R. Brent, R.E. Kingston, D.D. Moore, J.G. Seidman, J.A. Smith, and K. Struhl. 1987. Curr. Protocols in Mol. Biol., Greene Publishing Associates/Wiley Interscience, New York.

Bernard, B. 2007. Access excellence the national health museum, Isolation of Antibiotic strins from soils (www.access excellence.org).

Clarridge, J.E. 2004. "Impact of $16 \mathrm{~S}$ rRNA gene sequence analysis for identification of bacteria on clinical microbiology and infectious diseases.",Clin. Microbiol. Rev., 17(4): 840-62.

Schaffer, P. 1969. Sporulation and the production of antibiotics, exoenzymes, and exotoxins. Bacteriol. Rev., 33: 48 71.

Demain, A.L. and Davies, J.E. 1999. Manualof Industrial Microbiology and Biotechonology $2^{\text {nd }}$ edition (Chapter-1, page-3-20). American Soc. Microbiol., Washington.

Tay, W., Epperson, J., da Silva, G., Ming, L. 2010. NMR, mechanism and mononuclear oxidative activity of the antibiotic metallopeptide bacitracin: the role of D-glu-4, interaction with pyrophosphate moity, DNA binding and cleavage, and bioactivity, J. American Chem. Soc., 132: 5652-5661.

\section{How to cite this article:}

Aurpita Shaha, Ariful Haque, Uzzal Haque and Anwar Ul Islam. 2016. Identification of Bacteria that Contaminate Stored Streptomycin Species at $4^{\circ}$ C. Int.J.Curr.Microbiol.App.Sci. 5(8): 617-625. doi: http://dx.doi.org/10.20546/ijcmas.2016.509.070 